https://doi.org/10.30910/turkjans.680065

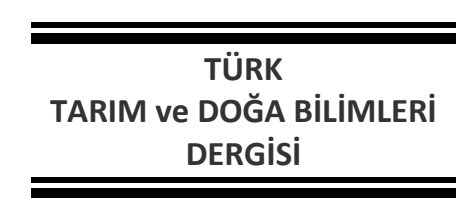

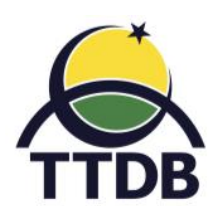

www.dergipark.gov.tr/turkjans

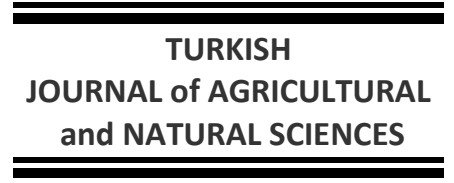

Araştırma Makalesi

\title{
iki Lokasyonda Sıra Arası Mesafe ve Ekim Sıklığının Karabuğday Çeşitlerinin Tane Verimi ve Ham Protein Oranı Üzerine Etkisi ${ }^{\S}$
}

\author{
Sevim AKÇURA ${ }^{1 *}$, Bahri izCi², Kağan KÖKTEN ${ }^{3}$, Selim ÖZDEMiR ${ }^{4}$ \\ ${ }^{1}$ Çanakkale Onsekiz Mart Üniversitesi, Fen Bilimleri Enstitüsü Tarla Bitkileri Anabilim Dalı, Çanakkale \\ ${ }^{2}$ Çanakkale Onsekiz Mart Üniversitesi, Ziraat Fakültesi, Tarla Bitkileri Bölümü, Çanakkale \\ ${ }^{3}$ Bingöl Üniversitesi, Ziraat Fakültesi, Tarla Bitkileri Bölümü, Bingöl \\ ${ }^{4}$ Bingöl Üniversitesi, Teknik Bilimler MYO, Bitkisel ve Hayvansal Üretim Bölümü, Tarla Bitkileri Programı, Bingöl \\ *Sorumlu yazar: sevimakcura@yahoo.com
}

\begin{abstract}
Geliş Tarihi: 26.10 .2019
Düzeltme Geliş Tarihi: 30.12.2019

Kabul Tarihi: 10.01.2020

\section{Özet}

Bu çalışma Çanakkale ve Bingöl lokasyonlarında Aktaş ve Güneş karabuğday çeşitlerinde tane verimi ve ham protein oranı için uygun sıra arası mesafe (SAM) ve tohum sayısını (TS) belirlemek amacıyla yürütülmüştür. Her iki lokasyonda denemeler bölünen bölünmüş parseller deneme desenine göre 3 tekerrürlü olarak kurulmuştur. Bingöl lokasyonunda varyans analizinde hem tane verimi hem de ham protein oranında SAM, TS, Çeşit (Ç) $x$ SAM, Ç $x$ TS, SAM $x$ TS ve Ç $x$ SAM x TS interaksiyonları istatistiksel olarak $P<0.01$ düzeyinde önemli bulunmuştur. Çanakkale lokasyonunda ise varyans analizi sonuçlarına göre tane veriminde çeşitler hariç diğer varyasyon kaynakları istatistiksel olarak $\mathrm{P}<0.01$ düzeyinde önemli iken ham protein oranında ise varyasyon kaynaklarının tamamı arasındaki farklar istatistiksel olarak önemsiz olmuştur. Her iki lokasyonda da tane verimi ve protein oranında uygun olan SAM ve TS belirlemek için regresyon grafikleri oluşturulmuştur. Regresyon analizinde her iki çeşitte en yüksek tane verimleri hem Çanakkale hem de Bingöl koşullarında $25 \mathrm{~cm}$ sıra arası mesafe ve $300 \mathrm{adet} / \mathrm{m}^{2}$ tohum sayısında tespit edilmiştir. Ham protein oranında ise Çanakkale'de Aktaş çeşidinde en yüksek değerler 12.5 ve $25 \mathrm{~cm}$ mesafede 300 adet tohum sıklığından elde edilirken, Güneş çeşidinde ise tohum sayısı ve sıra arası mesafeye bağı olarak ham protein eğrileri değişim göstermiş olsa da ortalamalar birbirine yakın olmuştur. Bingöl koşullarında ham protein oranında ise hem Aktaş hem de Güneş çeşitlerinde en yüksek ham protein oranı $12.5 \mathrm{~cm}$ sıra arası mesafede 100 adet tohum sayısında tespit edilmiştir. Denemelerin yürütüldüğü bölgelerimizde tane amaçlı karabuğday yetiştiriciliğinde $25 \mathrm{~cm}$ sıra arası ve 300 adet $/ \mathrm{m}^{2}$ tohum sayısının kullanılması yüksek tane verimi alınmasını sağlayacaktır. Ekim sıklığı ve tohum sayılarının faktör olarak değerlendirildiği araştırmalarda, varyans analizi yerine regresyon analizinin kullanılması daha yararlı olacaktır.
\end{abstract}

Anahtar kelimeler: Karabuğday, sıra arası mesafe, tohum sayısı, tane verimi, regresyon analizi.

\section{Influence of Row Spacing and Sowing Densities on Buckwheat Grain Yield and Crude Protein Ratio in two Locations}

\footnotetext{
Abstract

This study was carried out to determine suitable row spacing (RS) and seed number (SN) for grain yield and crude protein ratio in Aktaş and Güneş buckwheat cultivars in Çanakkale and Bingöl locations. Experiments in both locations were conducted with replications according to the split plots trial design. In the analysis of variance in Bingöl location, RS, SN, Variety (V) $x$ RS, V x SN, RS x SN and V x RS x SN interactions were statistically significant at $\mathrm{P}<0.01$ level. According to the results of variance analysis in the Çanakkale location, other variation sources except grain varieties were statistically significant at $P<0.01$ level, while differences between the crude protein content were statistically insignificant. Regression analysis graphs were used to determine the appropriate RS and SN ratios in grain yield and protein ratio in both locations. In the regression analysis, the highest grain yields of both cultivars were determined between $25 \mathrm{~cm}$ row spacing and 300 seeds $/ \mathrm{m}^{2}$ seed
} 
numbers in both Çanakkale and Bingöl conditions. In the ratio of crude protein, the highest values in Aktaş cultivar in Çanakkale were obtained from both 12.5 and $25 \mathrm{~cm}$ row spacing with $300 \mathrm{seeds} / \mathrm{m}^{2}$. In the Güneş variety, although the crude protein curves showed changes depending on the number of seeds and the row spacing, the averages were close to each other. In Bingöl conditions, the highest crude protein ratio in both Aktaş and Güneş varieties was determined as 100 seeds $/ \mathrm{m}^{2}$ at $12.5 \mathrm{~cm}$ row spacing. In the regions where the experiments are carried out, the use of the seed number between $25 \mathrm{~cm}$ row and 300 seeds $/ \mathrm{m}^{2}$ in grain buckwheat cultivation will provide high grain yield. The regression analysis instead of analysis of variance would be more useful in sowing frequency row spacing trials to determine the optimum sowing frequency and row spacing.

Key words: Buckwheat, row spacing, seed number, grain yield, regression analysis.

\section{Giriş}

Karabuğday geçmişi çok eskilere dayanan bir bitki olup Orta Asya kökenlidir. Illk olarak Hun İmparatorluğu, Çin ve Japonya'da yetiştirilen karabuğday bitkisi günümüzde birçok ülkede yetiştirilmektedir (Wijngaard ve Arendt, 2006). Özellikle Orta Asya Türk Cumhuriyetleri'nde yaygın kullanılan bir bitkidir. Karabuğday bitkisinin tohumlarından elde edilen un birçok hastalığın tedavi sürecinde kullanılabilecek özelliklere sahiptir, bu nedenle diabet hastaları için ideal bir besin kaynağı niteliğindedir.

İyi bir kimyasal kompozisyona sahip olması, özellikle lif ve protein içeriği bakımından zengin olması karabuğdayı tahıllardan ayırmaktadır (Christa ve Soral-Śmietana, 2008). Özellikle çölyak hastaları tarafından kullanılan bir bitki olması da karabuğdaya ayrı bir önem kazandırmaktadır. Türkiye'de karabuğday tarımı geniş alanlarda yapılmamaktadır. Ancak, özellikle glüten alerjisi olan insanlar için üretilmesi gerekmektedir.

Dünyada en fazla üretimi olan ülke Çin olup, bunu Rusya, Ukrayna, Kazakistan, Polonya, Brezilya, ABD, Kanada, Fransa izlemektedir (Campbell, 1997). Brunori ve ark. (2005) 2004 yılında iç İtalya ve güney Italya koşullarında kurdukları denemelerde, Güney Italya koşullarında tane veriminin $0.76 \mathrm{t} / \mathrm{ha}$ ile 1.53 t/ha arasında değiştiğini, elde edilen bu değerlerin yaygın yetiştiricilik ile benzer olduğunu, tane verimi ile vejetatif biyomasın yüksek oranda ilişkili olduğunu, karabuğdayda hasat indeksi değerlerinin 0.48-0.56 arasında değiştiğini belirlemişlerdir.

Bir çalışmada ise karabuğdayda bitki boyunun $66.27 \mathrm{~cm}$ ile $84.57 \mathrm{~cm}$ arasında, bitki başına dal sayısının ise 13.53 adet ile 27.47 adet arasında değişim gösterdiği bildirilmiştir (Debnath ve ark., 2008). Valenzuela ve Smith (2002) ise karabuğdayın bitki boyunun $60-150 \mathrm{~cm}$ arasında değiştiğini, çok dallı sukkulent bir sapa sahip olduğunu, çiçeklerinin beyaz veya açık yeşilden pembe veya kırmızıya kadar değiştiğini ifade etmişlerdir.

Nemin düşük olduğu, hava sıcaklığının yüksek olduğu ve kuru rüzgârların hâkim olduğu bölgelerde karabuğdayın tane verimi düşük olmaktadır (Acar, 2009). Bazı araştırıcılar tarafından karabuğdayın tavsiye edilen dekara bitki sayısının 170-180 bin arasında ve atılacak tohum miktarının 5- $6 \mathrm{~kg} / \mathrm{da}$ olduğu bildirilmiştir (Myers ve Meinke, 1994; Acar, 2009). Acar ve ark., (2011) Konya koşullarında iki yıl süre ile karabuğdayda uygun ekim normunu belirlemek amacıyla bir araştırma yürütmüşler, araştırmada en yüksek sap verimi $1784 \mathrm{~kg} / \mathrm{da}$ ile $20 \mathrm{~cm}$ sıra aralığında ve en fazla tohum verimi $101 \mathrm{~kg} / \mathrm{da}$ ile $40 \mathrm{~cm}$ sıra aralığında birinci deneme yılında elde etmişlerdir. Karaman'da ikinci ürün olarak yetiştirilen karabuğdayda vejetasyon süresinin 74.46-89.02 gün, bitki boyunun $42.60-98.67 \mathrm{~cm}$, tane veriminin 42.54$115.78 \mathrm{~kg} / \mathrm{da}$ arasında değişim gösterdiği bildirilmiştir (Güzelsarı ve Kan, 2017). Eskişehir koşullarında yürütülen bir araştırmada Aktaş çeşidinin $12 \mathrm{~kg} / \mathrm{da}$ tohumluk kullanılarak yetiştirilmesi önerilmiştir (Katar ve Katar, 2017). Yavuz ve ark. (2016) tarafından farklı tohumluk miktarları kullanılarak yürütülen bir başka araştırmada ise tane veriminin $244.2-297.7 \mathrm{~kg} / \mathrm{da}$, bin tane ağırlığının 25.6-30.7 g, bitki boyunun 64.7$71.7 \mathrm{~cm}$, metrekarede bitki sayısının 23.5-64.0 adet, tanede protein oranının \%11.75-12.56 ve hektolitre ağırlığının $60.1-61.0 \mathrm{~kg} / \mathrm{hl}$ arasında değişim gösterdiği, Aydın ekolojik koşullarında 8 kg/da'lık tohumluk miktarının yeterli olduğu sonucuna varılmıştır.

Bu çalışma Bingöl ve Çanakkale koşullarında ana ürün olarak yetiştirilen Aktaş ve Güneş karabuğday çeşitlerinin tane verimi ve ham protein oranı bakımından uygun ekim sıklığı ve sıra arası mesafesini belirlemek amacıyla yürütülmüştür.

\section{Materyal ve Yöntem}

Araştırma 2012 yılında Çanakkale ve 2014 yılında ise Bingöl koşullarında üç farklı sıra arası mesafe, dört farklı tohum adedi kullanılarak Bahri Dağdaş Uluslararası Tarımsal Araştırma Enstitüsü tarafından geliştirilen Aktaş ve Güneş karabuğday çeşitleri ile yürütülmüştür.

İki lokasyonda deneme yerinden $20 \mathrm{~cm}$ derinlikten ekim işleminden önce toprak özelliklerini belirlemek için toprak örneği alınmıştır. 
Toprak analizi sonuçlarına göre Çanakkale lokasyonu deneme arazisinin toprakları kireçli (\%13.69) organik madde içeriği düşük (\%1.28), hafif alkali ( $\mathrm{pH}=7.82$ ), Bingöl lokasyonu ise kireçli (\%15), organik madde içeriği düşük (\%1.26) ve hafif asidik ( $\mathrm{pH}=6.37)$ yapılıdır.

Denemeler bölünen bölünmüş parseller deneme desenine göre üç tekerrürlü olarak kurulmuştur. Çeşitler (Aktaş ve Güneş) ana parsellerde yer alırken, alt parsellerde sıra arası mesafeler $(12.5 \mathrm{~cm}, 25.0 \mathrm{~cm}$ ve $37.5 \mathrm{~cm})$ ve altın-altı parsellerde de ekim sıklıkları (100 adet $/ \mathrm{m}^{2}, 200$ adet $/ \mathrm{m}^{2}, 300 \mathrm{adet} / \mathrm{m}^{2}$ ve $400 \mathrm{adet} / \mathrm{m}^{2}$ ) yer almıştır. Denemelerin ekim işlemi el markörü kullanılarak yapılmıştır. Parsel boyutları $1.5 \mathrm{~m} \times 4 \mathrm{~m}=6 \mathrm{~m}^{2}$ olarak belirlenmiş ve her parsel arasına $50 \mathrm{~cm}$ mesafe bırakılmıştır. Ekim esnasında 15:15:15 gübresinden $8 \mathrm{~kg} /$ da N, P ve K olacak şekilde gübre verilmiştir. Çanakkale'de denemenin ekimi 05 Mayıs 2012, Bingöl'de 26 Nisan 2014 tarihinde yapılmıştır. Denemeler her iki lokasyonda 3 kez salma sulama şeklinde sulanmıştır. Denemelerde yabancı ot mücadelesi el ile yapılmıştır. Hasat işlemi orak ile harman işlemi ise parsel harman makinası ile yapılmıştır. Araştırmada tane verimi (kg/da) ve tanede ham protein oranı (\%) özellikleri incelenmiştir. Ham protein oranı değirmende öğütülen tane örneklerinde Kheldal yöntemine göre belirlenmiştir.

Araştırmada incelenen özelliklere ait verilerde öncelikle JMP istatistik analiz programında varyans analizi ve sonra regresyon analizleri yapılmıştır (JMP SAS Institute, 2016).

\section{Bulgular ve Tartışma}

Çanakkale ve Bingöl'de kurulan denemelerin tane verimine ait varyans analizi sonuçları ile lokasyonlara göre, tüm varyasyon kaynaklarına ait ortalamalar ile $\mathrm{F}$ testine göre önemli olan faktörlere (sıra arası mesafeler ve ekim sıklıkları) ait LSD testi sonuçları Çizelge 1 de verilmiştir.

Çizelge 1. Lokasyonlara ve uygulamalara göre tane verimleri (kg/da).

\begin{tabular}{|c|c|c|c|c|c|c|c|c|}
\hline \multicolumn{9}{|c|}{ Aktaş } \\
\hline \multicolumn{5}{|c|}{ Çanakkale } & \multicolumn{4}{|c|}{ Bingöl } \\
\hline \multirow{2}{*}{$\begin{array}{c}\text { TS } \\
\left(\text { adet } / \mathrm{m}^{2}\right)\end{array}$} & \multicolumn{4}{|c|}{ SAM $(\mathrm{cm})$} & \multicolumn{4}{|c|}{ SAM $(\mathrm{cm})$} \\
\hline & 12.5 & 25 & 37.5 & $\bar{X}$ & 12.5 & 25 & 37.5 & $\bar{X}$ \\
\hline 100 & 56 & 127 & 127 & 103 & 45 & 82 & 157 & 95 \\
\hline 200 & 128 & 164 & 186 & 159 & 115 & 127 & 189 & 144 \\
\hline 300 & 112 & 274 & 250 & 212 & 125 & 220 & 164 & 170 \\
\hline 400 & 134 & 219 & 166 & 173 & 121 & 206 & 159 & 162 \\
\hline $\bar{X}$ & 108 & 196 & 182 & 162 & 102 & 159 & 167 & 143 \\
\hline \multicolumn{9}{|c|}{ Güneş } \\
\hline \multicolumn{5}{|c|}{ Çanakkale } & \multicolumn{4}{|c|}{ Bingöl } \\
\hline TS & \multicolumn{4}{|c|}{ SAM (cm) } & \multicolumn{4}{|c|}{ SAM (cm) } \\
\hline$\left(\right.$ adet $\left./ \mathrm{m}^{2}\right)$ & 12.5 & 25 & 37.5 & $\bar{X}$ & 12.5 & 25 & 37.5 & $\overline{\boldsymbol{X}}$ \\
\hline 100 & 129 & 127 & 141 & 132 & 144 & 131 & 140 & 138 \\
\hline 200 & 171 & 167 & 237 & 192 & 154 & 163 & 226 & 181 \\
\hline 300 & 232 & 274 & 175 & 227 & 198 & 245 & 182 & 208 \\
\hline 400 & 62 & 218 & 190 & 157 & 85 & 193 & 148 & 142 \\
\hline $\bar{X}$ & 149 & 196 & 186 & 177 & 145 & 183 & 174 & 167 \\
\hline \multicolumn{9}{|c|}{ Ortalama } \\
\hline \multicolumn{5}{|c|}{ Çanakkale } & \multicolumn{4}{|c|}{ Bingöl } \\
\hline TS & \multicolumn{4}{|c|}{ SAM (cm) } & \multicolumn{4}{|c|}{ SAM (cm) } \\
\hline$\left(\right.$ adet $\left./ \mathrm{m}^{2}\right)$ & 12.5 & 25 & 37.5 & $\overline{\boldsymbol{X}}^{¥}$ & 12.5 & 25 & 37.5 & $\overline{\boldsymbol{X}}$ \\
\hline 100 & 93 & 127 & 134 & $118 \mathrm{c}$ & 94 & 107 & 148 & $116 c$ \\
\hline 200 & 150 & 165 & 212 & $176 b$ & 135 & 145 & 207 & $162 b$ \\
\hline 300 & 172 & 274 & 213 & $220 a$ & 162 & 233 & 173 & $189 a$ \\
\hline 400 & 98 & 218 & 178 & $165 b$ & 103 & 200 & 153 & $152 b$ \\
\hline $\bar{X}$ & $128 \mathrm{~b}$ & $196 a$ & $184 a$ & 169 & $124 b$ & $171 a$ & $170 a$ & 155 \\
\hline
\end{tabular}

$\bar{X}$ : Ortalama, TS (adet/m2): Tohum sayısı, SAM (cm): Sıra arası mesafe Çeşitler (Ç): Öd, SAM: **, TS: **, Ç x SAM: **, Ç x TS: öd, SAM x TS: **, Ç x SAM x TS: **

$\begin{array}{lll}\% \text { DK } & 11.35 & 7.5\end{array}$

Öd: önemli değil, **: P<0.01 düzeyinde önemlidir.

¥: Tohum sayısı ve sıra arası mesafelerde aynı harf ile gösterilen ortalamalar arasında istatistiksel olarak $P<0.01$ önem düzeyinde fark yoktur. 
Çanakkale lokasyonunda deneme ortalaması $169 \mathrm{~kg} / \mathrm{da}$, Bingöl lokasyonunda ise $155 \mathrm{~kg} / \mathrm{da}$ olarak tespit edilmiştir. Çeşitler arasındaki fark her iki lokasyonda istatistiksel olarak önemsiz olmuştur. Hem Çanakkale hem de Bingöl lokasyonunda tane verimi bakımından sıra arası mesafeler arasındaki farkların istatistiki olarak önemli olduğu tespit edilmiştir $(P<0.01)$. Çanakkale lokasyonunda en yüksek tane verimi $25 \mathrm{~cm}$ sıra arası mesafeden (196 $\mathrm{kg} / \mathrm{da}$ ) elde edilirken, ikinci sıradaki tane verimi 37.5 $\mathrm{cm}$ sıra arası mesafeden ( $184 \mathrm{~kg} / \mathrm{da}$ ) elde edilmiştir. $12.5 \mathrm{~cm}$ sıra arası mesafe ise $128 \mathrm{~kg} / \mathrm{da}$ tane verimi vermiştir. LSD testi sonuçlarına göre iki ortalama grubu oluşmuştur. $25 \mathrm{~cm}$ ve $37.5 \mathrm{~cm}$ sıra arası birinci ortalama grubunu (a) oluştururken, $12,5 \mathrm{~cm}$ sıra arası mesafe ikinci ortalama grubunu (b) oluşturmuştur (Çizelge 1). Bingöl lokasyonunda tane verimi bakımından sıra arası mesafeler LSD testine göre iki ortalama grubu oluşturmuş, birinci ortalama grubunda 171 ve $170 \mathrm{~kg} / \mathrm{da}$ tane verimi ile 25 ve $37.5 \mathrm{~cm}$ sıra arası mesafe yer almıştır. İkinci ortalama grubunda ise $124 \mathrm{~kg} / \mathrm{da}$ tane verimi ile $12.5 \mathrm{~cm}$ sıra arası mesafe yer almıştır.

Tane verimi bakımından tohum sayıları arasındaki farkların iki lokasyonda da istatistiki olarak önemli olduğu $(\mathrm{P}<0.01)$ belirlenmiştir (Çizelge 1). Çanakkale lokasyonunda tohum sayılarına bağlı olarak karabuğday çeşitlerinin tane verimleri $118 \mathrm{~kg} /$ da ile $220 \mathrm{~kg} /$ da arasında, Bingöl lokasyonunda ise $116 \mathrm{~kg} /$ da ile $189 \mathrm{~kg} / \mathrm{da}$ arasında değişim göstermiştir.

Çanakkale lokasyonunda en yüksek tane verimi 300 adet $/ \mathrm{m}^{2}$ ekim sıklığından $(220 \mathrm{~kg} / \mathrm{da})$ elde edilirken, ikinci sıradaki tane verimi 200 adet $/ \mathrm{m}^{2}$ ekim sıklığından (176 kg/da), üçüncü sıradaki tane verimi 400 adet $/ \mathrm{m}^{2}$ ekim sıklığından $(165 \mathrm{~kg} / \mathrm{da})$ elde edilmiştir. En düşük tane verimi ise 100 adet $/ \mathrm{m}^{2}$ ekim sıklığından 118 kg/da elde edilmiştir (Çizelge 1).

İki lokasyonda da çeşit x sıra arası mesafe, çeşit $x$ tohum sayısı, tohum sayısı $x$ sıra arası mesafe ve çeşit $x$ tohum sayısı $x$ sıra arası mesafe interaksiyonları istatistiksel olarak önemli $(P<0.01)$ bulunmuştur (Çizelge 1). Söz konusu interaksiyonları görsel olarak değerlendirmek ve her iki lokasyonda tane verimi bakımından en uygun çeşit, sıra arası mesafe ve tohum sayısını tespit etmek amacıyla çeşitler üzerine, sıra arası mesafeler ve tohum sayılarının dağıtılması ile oluşturulan regresyon eğrileri Şekil 1a, b ve c'de verilmiştir.

Şekil 1a'da görüldüğü gibi en üst çerçeveden bakıldığı zaman Çanakkale lokasyonunda çeşitlerin özellikle 100 adet $/ \mathrm{m}^{2}$ ve 200 adet $/ \mathrm{m}^{2}$ tohum sıklıklarındaki sıra arası mesafelere verdiği tepkiler oldukça farklı olmuştur. 100 adet $/ \mathrm{m}^{2}$ tohum sıklığında Aktaş çeşidinin $25 \mathrm{~cm}$ ve $37.5 \mathrm{~cm}$ sıra arası mesafelerdeki tane verimleri birbirine benzer iken, en düşük tane verimi $12.5 \mathrm{~cm}$ 'den elde edilmiştir. Güneş çeşidinde ise üç ekim sıklığından elde edilen tane verimleri birbirine yakın gerçekleşmiştir (Şekil 1a).

200 adet $/ \mathrm{m}^{2}$ ekim sıklığında hem Aktaş hem de Güneş çeşitlerinde en yüksek tane verimleri 37.5 $\mathrm{cm}$ sıra arası mesafede belirlenmiş iken, en düşük tane verimleri ise $12.5 \mathrm{~cm}$ sıra arası mesafen elde edilmiştir. 300 ve 400 adet $/ \mathrm{m}^{2}$ ekim sıklıklarında ise her iki çeşidin ekim sıklıklarına verdiği reaksiyona bağı olarak regresyon eğrileri benzer olmuştur. Ancak, 300 adet $/ \mathrm{m}^{2}$ de Güneş çeşidinin $12.5 \mathrm{~cm}$ sıra arası mesafedeki tane verimi $(232 \mathrm{~kg} / \mathrm{da})$ Aktaş çeşidinin yaklaşık olarak iki katı (112 kg /da) olmuştur (Çizelge 1). Çanakkale lokasyonunda iki çeşidin en yüksek tane verimleri $25 \mathrm{~cm}$ sıra arası mesafelerde 300 ve 400 adet $/ \mathrm{m}^{2}$ tohum sayısında elde edilmiştir.

Bingöl lokasyonunda tohum sayısına bağlı olarak tane verimi $116 \mathrm{~kg} / \mathrm{da}$ (100 adet/m²) ile 189 $\mathrm{kg} / \mathrm{da}\left(300 \mathrm{adet} / \mathrm{m}^{2}\right)$ arasında değişim göstermiştir. Bu lokasyonda LSD testi sonucuna göre 300 adet $/ \mathrm{m}^{2}$ birinci ortalama grubunu oluştururken, 200 adet $/ \mathrm{m}^{2}$ ve $400 \mathrm{adet} / \mathrm{m}^{2}$ tohum sayıları sırasıyla $162 \mathrm{~kg} / \mathrm{da}$ ve $152 \mathrm{~kg} /$ da tane verimleriyle ikinci ortalama grubunu oluşturmuştur. Bu lokasyonda sıra arası mesafelerin tane verimleri $124 \mathrm{~kg} / \mathrm{da}(12.5 \mathrm{~cm})$ ile $171 \mathrm{~kg} / \mathrm{da}(25$ $\mathrm{cm}$ ) arasında değişim göstermiştir. LSD testine göre sıra arası mesafeler iki ortalama grubunu oluşturmuştur. Birinci ortalama grubunda $171 \mathrm{~kg} / \mathrm{da}$ ile $25 \mathrm{~cm}$ ve $170 \mathrm{~kg} / \mathrm{da}$ ile $37.5 \mathrm{~cm}$ yer alırken, ikinci ortalama grubunda $124 \mathrm{~kg} / \mathrm{da}$ tane verimi $12.5 \mathrm{~cm}$ yer almıştır (Çizelge 1).

Bingöl koşullarında Aktaş çeşidinin tane sayılarına göre tane verimleri $95 \mathrm{~kg} / \mathrm{da}(100$ adet $/ \mathrm{m}^{2}$ ) ile $170 \mathrm{~kg} / \mathrm{da}$ (300 adet $/ \mathrm{m}^{2}$ ) arasında değişim göstermiştir. Bu lokasyonda sıra arası mesafelere göre Aktaş çeşidinin tane verimi 102 $\mathrm{kg} / \mathrm{da}(12.5 \mathrm{~cm}), 167 \mathrm{~kg} / \mathrm{da}$ arasında $(37.5 \mathrm{~cm})$ değişim göstermiştir (Çizelge 1).

Güneş çeşidinin Bingöl lokasyonunda tane verimi tane sayısına bağlı olarak $138 \mathrm{~kg} / \mathrm{da}(100$ adet $/ \mathrm{m}^{2}$ ) ile $208 \mathrm{~kg} / \mathrm{da}$ (300 adet $/ \mathrm{m}^{2}$ ) arasında değişim göstermiştir. Bu çeşidin sıra arası mesafelere bağlı olarak tane verimi $145 \mathrm{~kg} / \mathrm{da}$ (12.5 $\mathrm{cm})$ ile $183 \mathrm{~kg} / \mathrm{da}(25 \mathrm{~cm})$ arasında değişim göstermiştir (Çizelge 1). 


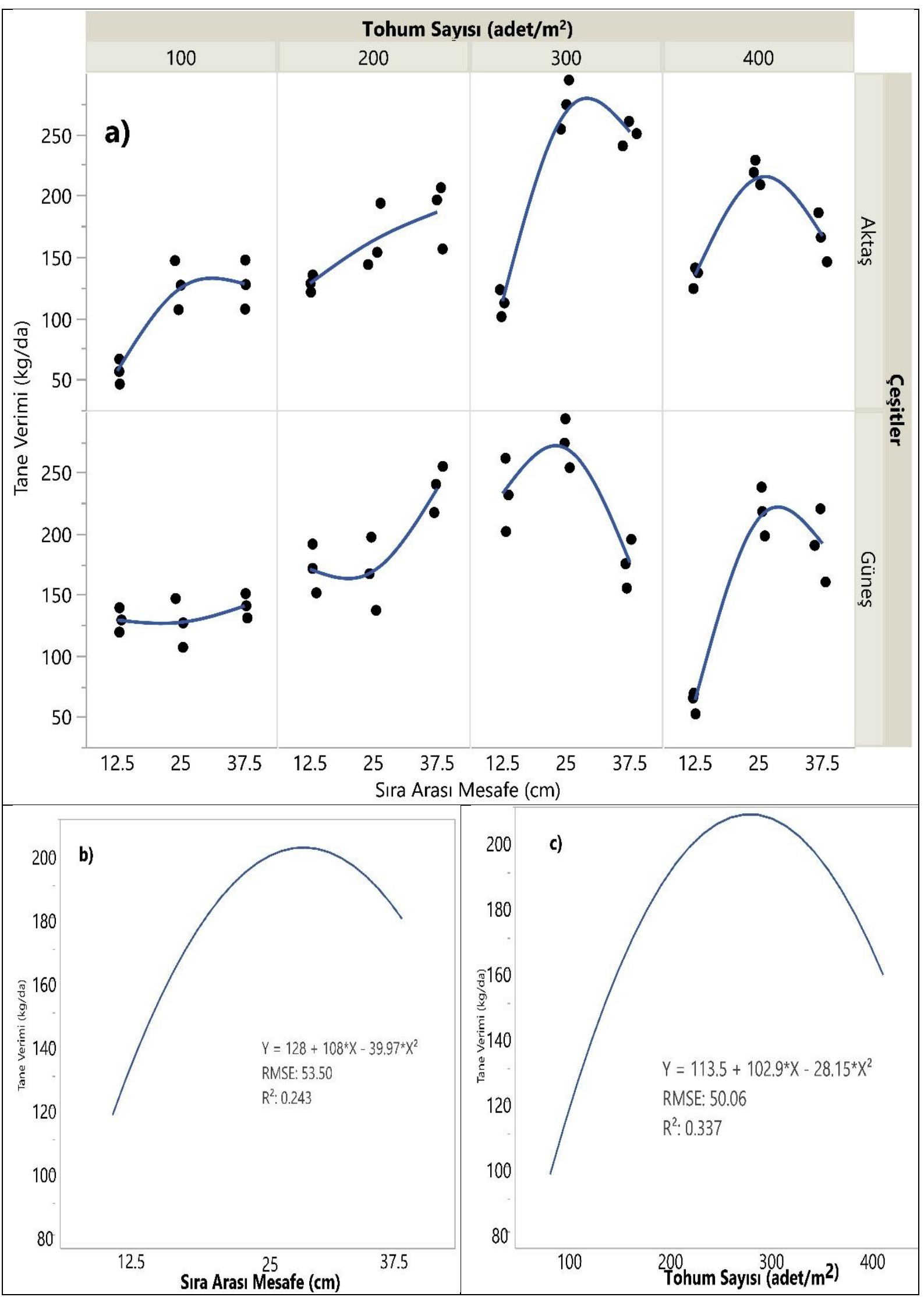

Şekil 1. a) Çanakkale lokasyonunda tane veriminde çeşit $x$ sıra arası $x$ tohum sayısı interaksiyonu, b) Sıra arası mesafeye göre tane verimi c) Tohum sayısına göre tane verimi. 


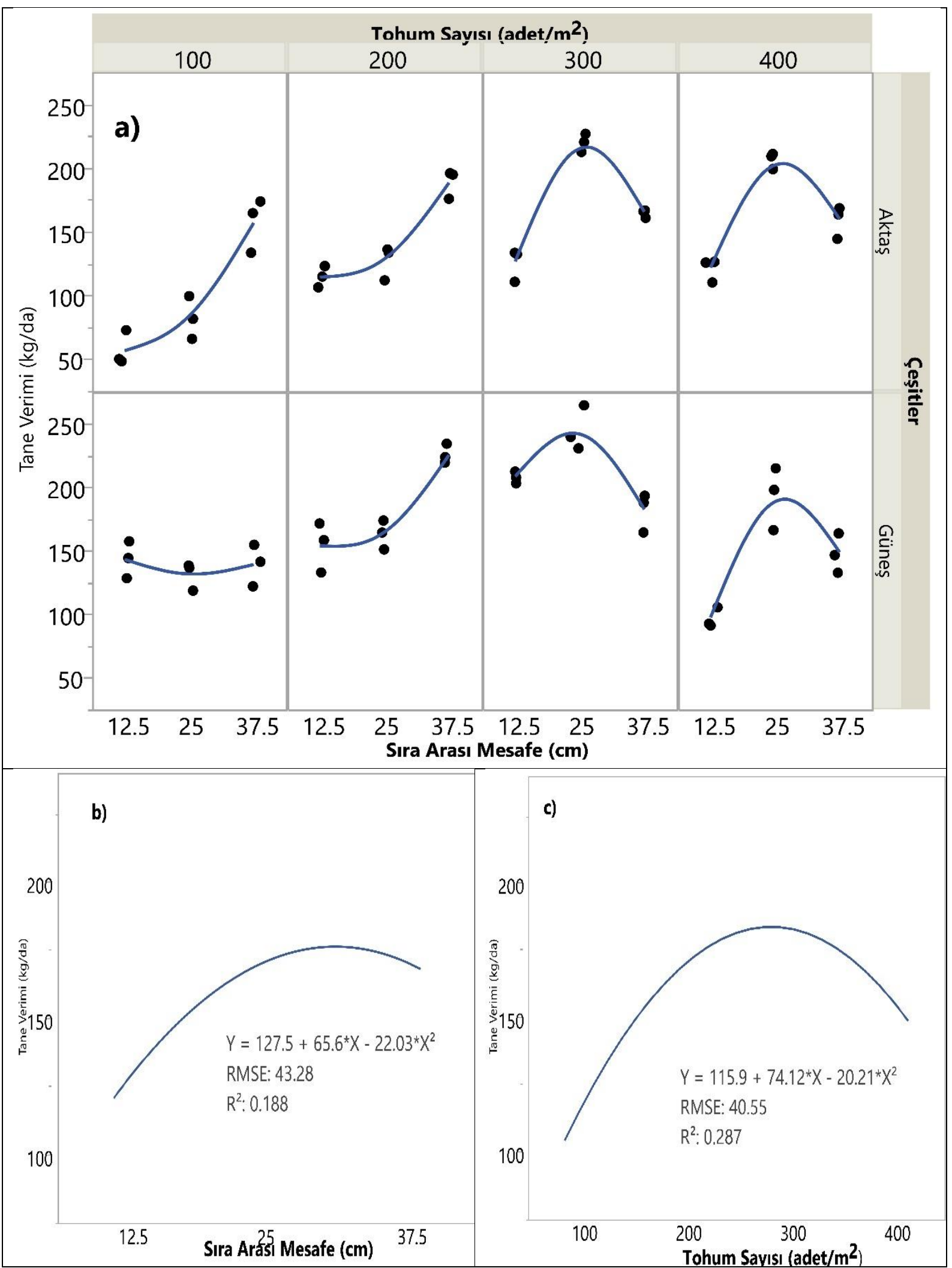

Şekil 2. a) Bingöl lokasyonunda tane veriminde çeşit $x$ sıra arası $x$ tohum sayısı interaksiyonu, b) Sıra arası mesafeye göre tane verimi c) Tohum sayısına göre tane verimi.

Bingöl lokasyonunda interaksiyonları açıklamak amacıyla çeşitlere göre oluşturulan regresyon grafikleri Şekil 2a'da gösterilmiştir. Bu lokasyonda 100 adet $/ \mathrm{m}^{2}$ tohum sayısı hariç çeşitlerin tohum sayısına ve sıra arası mesafelere bağlı olarak vermiş olduğu reaksiyonlar en düşük ve en yüksek değerler farklı olarak şekilsel açıdan birbirine benzer gerçekleşmiştir. Çanakkale 
lokasyonunda olduğu gibi, 300 adet ve 400 adet tohum sıklıklarında her iki çeşitte de en yüksek tane verimi $25 \mathrm{~cm}$ sıra arası mesafede elde edilmiştir (Şekil 2a).

200 adet $/ \mathrm{m}^{2}$ tohum sayısında ise iki çeşidin tane verimlerindeki değişim birbirine benzer olmuştur. Bu tohum sayısında en düşük tane verimi $12.5 \mathrm{~cm}$ sıra arasında elde edilmiş iken, en yüksek tane verimi $37.5 \mathrm{~cm}$ sıra arası mesafeden elde edilmiştir.

İki lokasyonda da tüm veriler üzerinden oluşturulan regresyon grafiklerine göre ana ürün olarak yetiştirilen karabuğdayda en yüksek tane verimi $25 \mathrm{~cm}$ sıra arası mesafeden elde edilmiştir (Şekil 1b, Şekil 2b). İki lokasyonda tane verimi üzerinden yapılan regresyon analizine göre en yüksek tane verimleri 300 adet $/ \mathrm{m}^{2}$ tohum sayısında tespit edilmiştir (Şekil 1c, 2c).

Gubbels ve Campbell (1986) iri tohumlu Mancan ve Manor karabuğday çeşitleri ve yarı bodur hatları kullanarak üç yıl süreyle 15, 30, 45 ve $60 \mathrm{~kg} / \mathrm{ha}$ ekim sıklığının etkisini belirlemek amacıyla yürüttükleri araştırmalarında optimum verim için 30 ve 45 kg/ha ekim sıklığının kullanılması gerektiğini önermişlerdir. Park ve ark. (2001) tetraploid karabuğday çeşitlerinin diploid olanlardan daha verimli olduğunu, en yüksek tane veriminin $40 \mathrm{~cm} \mathrm{x}$ $10 \mathrm{~cm}$ ekim sıklığından elde edildiğini bildirmişlerdir. Denememizin amacına benzer şekilde Janos ve Gocs (2009) tarafından yürütülen bir araştırmada 12, 24, 36 ve $48 \mathrm{~cm}$ sıra arası mesafelerde $125 \mathrm{bitki} / \mathrm{m}^{2}, 250 \mathrm{bitki} / \mathrm{m}^{2}, 375$ bitki $/ \mathrm{m}^{2}$ ve 500 bitki $/ \mathrm{m}^{2}$ ekim sıklıkları kullanılmış, bitki sayısına bağı ılarak en yüksek tane verimini (196.3 kg/da) 375 bitki $/ \mathrm{m}^{2}$ den, sıra arası mesafeye bağlı olarak en yüksek tane verimini $36 \mathrm{~cm}$ sıra arası mesafeden elde edilmiştir.

İç Anadolu koşullarında en yüksek yeşil ot verimi $20 \mathrm{~cm}$ sıra arası mesafede, en yüksek tane verimi ise $40 \mathrm{~cm}$ sıra arası mesafeden elde edilmiştir (Acar ve ark., 2011). Eskişehir koşullarında yürütülen bir araştırmada ise $12 \mathrm{~kg} / \mathrm{da}$ tohumluk miktarının karabuğdayda yüksek verim için yeterli olduğu bildirilmiştir (Katar ve Katar, 2017). Yavuz ve ark. (2016) ise Aydın ekolojik koşullarında yürütmüş oldukları çalışmada karabuğdayda tane veriminin 244-288 kg/da arasında değiştiğini ve en uygun tohumluk miktarını ise $8 \mathrm{~kg} / \mathrm{da}$ olarak tespit etmişlerdir.

Varyans analizi sonuçlarına göre Çanakkale lokasyonunda tanede ham protein oranı bakımından tüm muameleler ve muameler arasındaki interaksiyonlar istatistiksel olarak önemsiz olmuştur. Aktaş çeşidinin ortalama ham protein oranı \%9.7, Güneş çeşidinin ise \%9.3 olmuştur. Ham protein oranı hem sıra arası mesafe hem de tohum sayısından varyans analizi sonuçlarına göre istatistiksel olarak önemli düzeyde etkilenmemiştir. Aktaş çeşidinde 300 adet $/ \mathrm{m}^{2}$ tohum sayısında en yüksek ham protein oranı $\% 10.0$ olarak belirlenmişken, $12.5 \mathrm{~cm}$ ve $25 \mathrm{~cm}$ sıra arasında 300 adet $/ \mathrm{m}^{2}$ sıklığında sırasıyla \%10.4 ve \%10.3 olarak gerçekleşmiştir (Çizelge 2). Güneş çeşidinin tüm uygulamalarında tespit edilen protein oranı \%9.3 olmuştur. Regresyon analizi sonuçlarına göre Çanakkale lokasyonunda Aktaş çeşidinde farklı tohumluk miktarlarında ve sıra arası mesafelerde elde edilen ham protein oranları tahmin eğrileri birbirinden farklı olmuştur. $100 \mathrm{adet} / \mathrm{m}^{2}$ tohumluk adetinde en yüksek ham protein oranı $25 \mathrm{~cm}$ sıra arası mesafede, 200 adet $/ \mathrm{m}^{2}$ tohum sayısında 37.5 $\mathrm{cm}, 300$ adet $/ \mathrm{m}^{2}$ tohum sayısında $12.5 \mathrm{~cm}, 400$ adet $/ \mathrm{m}^{2}$ tohum sayısında ise $37.5 \mathrm{~cm}$ sıra arası mesafede elde edilmiştir (Şekil 3).

Çanakkale lokasyonunda Aktaş çeşidinde 100 adet $/ \mathrm{m}^{2}$ ve 400 adet $/ \mathrm{m}^{2}$ tohum sayılarındaki regresyon eğrileri benzer olurken, 200 ile 400 adet tohum sayılarındaki regresyon eğrileri de birbirine benzer olmuştur. Yukarıdaki ilk iki sıklıkta en yüksek ham protein oranı $12.5 \mathrm{~cm}$ mesafede, ikinci sıklıklarda ise $25 \mathrm{~cm}$ sıra arası mesafede elde edilmiştir. Varyans analizine göre istatistiksel olarak önemli farklılık olmasa da regresyon analizinde çeşit $x$ sıra arası mesafe $x$ tohum sayısı interaksiyonunun farklı olduğu görülmektedir (Şekil 3). Bu nedenle, ekim sıklığı, sıra arası mesafeler gibi faktörlerin olduğu denemelerde regresyon analizin yapılması elde edilen sonuçların daha sağlıklı değerlendirilmesini sağlayacaktır.

Bingöl lokasyonunda varyans analizi sonuçlarına göre ham protein oranında çeşitler arasındaki fark istatistiksel olarak önemsiz olurken, sıra arası mesafe, tohum adedi ve bu muamelelerin interaksiyonları istatistiksel olarak önemli $(P<0.01)$ bulunmuştur (Çizelge 2).

Bingöl lokasyonunda sıra arası mesafelerde en düşük ham protein oranı, \%9.1 ile $25 \mathrm{~cm}$ mesafede, en yüksek ham protein oranı \%10.1 olarak $12.5 \mathrm{~cm}$ mesafeden elde edilmiştir. $37.5 \mathrm{~cm}$ sıra arası mesafede ise ham protein oranı \%9.5 olarak gerçekleşmiştir. Sıra arası mesafelerin her birisi LSD testine göre ayrı ortalama gruplarında yer almıştır (Çizelge 2).

Tohum sayısına bağı olarak ham protein oranı \%9.3 ile (300 adet $\left./ \mathrm{m}^{2}\right) \% 9.8$ (100 adet $/ \mathrm{m}^{2}$ ) arasında değişim göstermiştir. Ham protein oranında LSD testine göre tohum adetleri üç ortalama grubu oluşturmuştur. Birinci ortalama grubunda \%9.8 ile 100 adet $/ \mathrm{m}^{2}$ ve \%9.7 ile 200 adet $/ \mathrm{m}^{2}$ olurken, ikinci ortalama grubunda $\% 9.5$ ile $400 \mathrm{adet} / \mathrm{m}^{2}$, üçüncü ortalama grubunda ise $\% 9.3$ ile 300 adet $/ \mathrm{m}^{2}$ tohum sayısı yer almıştır (Çizelge 2 ). 
Çizelge 2. Ham Protein oranının Lokasyonlara ve Uygulamalara göre değişimi

\begin{tabular}{|c|c|c|c|c|c|c|c|c|}
\hline \multicolumn{9}{|c|}{ Aktaş } \\
\hline \multicolumn{5}{|c|}{ Çanakkale } & \multicolumn{4}{|c|}{ Bingöl $^{f}$} \\
\hline \multirow{2}{*}{$\begin{array}{c}\text { TS } \\
\left(\text { adet } / \mathrm{m}^{2}\right)\end{array}$} & \multicolumn{4}{|c|}{ SAM (cm) } & \multicolumn{4}{|c|}{ SAM $(\mathrm{cm})$} \\
\hline & 12.5 & 25 & 37.5 & $\bar{X}$ & 12.5 & 25 & 37.5 & $\bar{X}$ \\
\hline 100 & 9.3 & 10.3 & 8.6 & 9.4 & 11.1 & 8.7 & 9.5 & 9.8 \\
\hline 200 & 9.7 & 9.6 & 10.1 & 9.8 & 10.3 & 9.3 & 10.7 & 10.1 \\
\hline 300 & 10.4 & 10.3 & 9.3 & 10.0 & 8.9 & 10.0 & 8.1 & 9.0 \\
\hline \multirow[t]{2}{*}{400} & 9.1 & 9.7 & 9.6 & 9.5 & 9.5 & 9.0 & 9.0 & 9.2 \\
\hline & 9.6 & 10.0 & 9.4 & 9.7 & 10.0 & 9.3 & 9.3 & 9.5 \\
\hline \multicolumn{9}{|c|}{ Güneş } \\
\hline \multicolumn{5}{|c|}{ Çanakkale } & \multicolumn{4}{|c|}{ Bingöl } \\
\hline TS & \multicolumn{4}{|c|}{ SAM (cm) } & \multicolumn{4}{|c|}{ SAM (cm) } \\
\hline$\left(\right.$ adet $\left./ m^{2}\right)$ & 12.5 & 25 & 37.5 & $\bar{X}$ & 12.5 & 25 & 37.5 & $\bar{X}$ \\
\hline 100 & 9.7 & 9.3 & 9.1 & 9.3 & 10.8 & 9.6 & 8.9 & 9.8 \\
\hline 200 & 9.4 & 9.7 & 9.0 & 9.4 & 9.7 & 8.0 & 10.1 & 9.3 \\
\hline 300 & 9.2 & 9.5 & 9.3 & 9.3 & 10.2 & 8.5 & 9.9 & 9.5 \\
\hline \multirow[t]{2}{*}{400} & 9.6 & 9.2 & 8.9 & 9.3 & 10.5 & 9.5 & 9.5 & 9.8 \\
\hline & 9.5 & 9.4 & 9.1 & 9.3 & 10.3 & 8.9 & 9.6 & 9.6 \\
\hline \multicolumn{9}{|c|}{ Ortalama } \\
\hline \multicolumn{5}{|c|}{ Çanakkale } & \multicolumn{4}{|c|}{ Bingöl } \\
\hline TS & \multicolumn{4}{|c|}{ SAM (cm) } & \multicolumn{4}{|c|}{ SAM $(\mathrm{cm})$} \\
\hline (adet/m $\left.\mathbf{m}^{2}\right)$ & 12.5 & 25 & 37.5 & $\overline{\bar{X}}$ & 12.5 & 25 & 37.5 & $\bar{X}$ \\
\hline 100 & 9.5 & 9.8 & 8.8 & 9.4 & 10.8 & 9.2 & 9.4 & $9.8 a$ \\
\hline 200 & 9.6 & 9.7 & 9.5 & 9.6 & 10.0 & 8.7 & 10.4 & $9.7 a$ \\
\hline 300 & 9.8 & 9.9 & 9.3 & 9.6 & 9.6 & 9.3 & 9.0 & $9.3 c$ \\
\hline \multirow[t]{2}{*}{400} & 9.4 & 9.5 & 9.3 & 9.4 & 10.1 & 9.2 & 9.2 & $9.5 b$ \\
\hline & 9.6 & 9.7 & 9.2 & 9.5 & $10.1 \mathrm{a}$ & $9.1 \mathrm{c}$ & $9.5 b$ & 9.6 \\
\hline
\end{tabular}

$\bar{X}$ : Ortalama, TS (adet/m2): Tohum sayısı, SAM (cm): Sıra arası mesafe

EBingöl için: Çeşitler (Ç): Öd, SAM: **, TS: **, Ç x SAM: **, Ç x TS: öd, SAM x TS: **, Ç x SAM x TS: **

\begin{tabular}{lll}
\hline DK & 5.44 & 2.20 \\
\hline
\end{tabular}

Öd: önemli değil, **: P<0.01 düzeyinde önemlidir.

¥: Çanakkale lokasyonunda varyasyon kaynaklarının tamamı arasındaki farklar istatistiksel olarak önemsizdir.

f: Tohum sayısı ve sıra arası mesafelerde aynı harf ile gösterilen ortalamalar arasında istatistiksel olarak $P<0.01$ önem düzeyinde fark yoktur.

Bingöl lokasyonunda tespit edilen ham protein oranlarının çeşitlere ve ekim sıklığı ve sıra arası mesafelere bağı olarak değişimleri Şekil 4'te verilmiştir. Şekilde görüldüğü gibi 200 ve 400 adet $/ \mathrm{m}^{2}$ de çeşitlerin sıra arası mesafelere reaksiyonu benzer olmuştur. $\mathrm{Bu}$ iki tohum sayısından birincisinde en düşük ham protein oranları $25 \mathrm{~cm}$ sıra arasından, en yüksek ham protein oranları ise $37.5 \mathrm{~cm}$ mesafeden elde edilmiştir. $12.5 \mathrm{~cm}$ sıra arası mesafe ise $37.5 \mathrm{~cm}$ mesafeden sonra yer almıştır. İkincisinde ise en yüksek protein oranları $12.5 \mathrm{~cm}$ sıra arası mesafeden, en düşük protein oranları ise $37.5 \mathrm{~cm}$ sıra arası mesafeden elde edilmiştir. Ham protein oranında en farklı değişim ise 300 adet $/ \mathrm{m}^{2}$ tohum sıklığında gerçekleşmiştir. Bu sıklıkta Aktaş çeşidinin en yüksek ham protein oranı $25 \mathrm{~cm}$ sıra arası mesafede tespit edilmiş iken, Güneş çeşidinin en yüksek ham protein oranı ise $12.5 \mathrm{~cm}$ arası mesafeden elde edilmiştir. 100 adet $/ \mathrm{m}^{2}$ sıklığında ise her iki çeşitte en yüksek ham protein oranı 12.5 $\mathrm{cm}$ sıra arası mesafede tespit edilmiştir. Tohum sayısı x sıra arası mesafe interaksiyonuna bakıldığı zaman en düşük ham protein oranı $25 \mathrm{~cm}$ de 200 adet $/ \mathrm{m}^{2}$ sıklığında yetiştirilen parsellerden, en yüksek ham protein oranı ise $12.5 \mathrm{~cm}$ mesafede 100 adet $/ \mathrm{m}^{2}$ ekim sıklığında yetiştirilen parsellerden elde edilmiştir (Şekil 4). Çalışmamızda elde etmiş olduğumuz ham protein oranları Eggum ve ark. (1980) tarafından bildirilen \%12 ham protein oranından düşüktür. Bárta ve ark. (2004)'nın bildirmiş olduğu \%11.12-12.21 değerlerinin alt sınırına yakındır. De Francischi ve ark. (1994) tarafından karabuğday ununda tespit edilen ham protein oranlarından (\%8.4-9.7) daha yüksektir. 


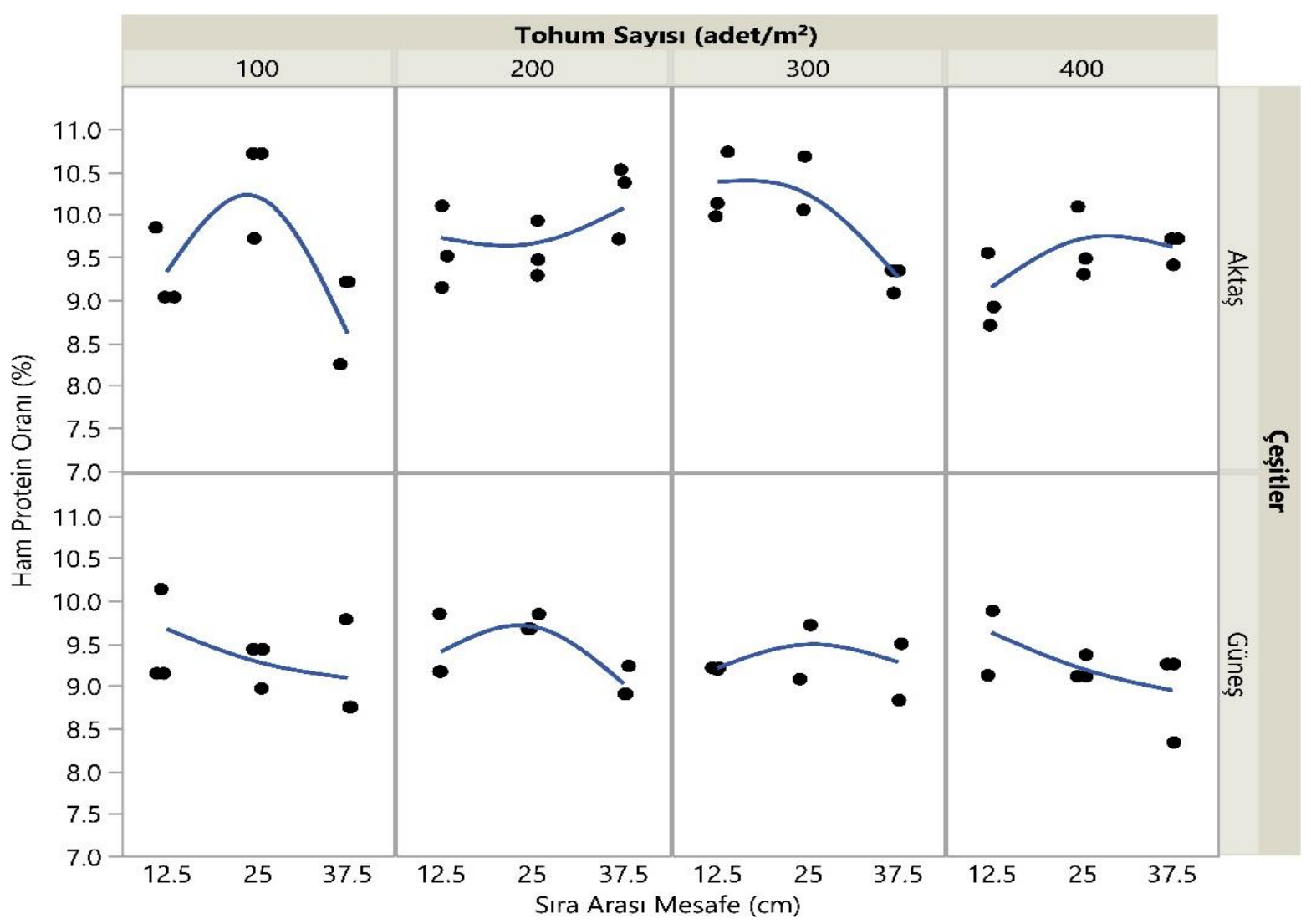

Şekil 3. Çanakkale lokasyonunda çeşit, sıra arası mesafe ve tohum sayılarına göre ham protein oranları.

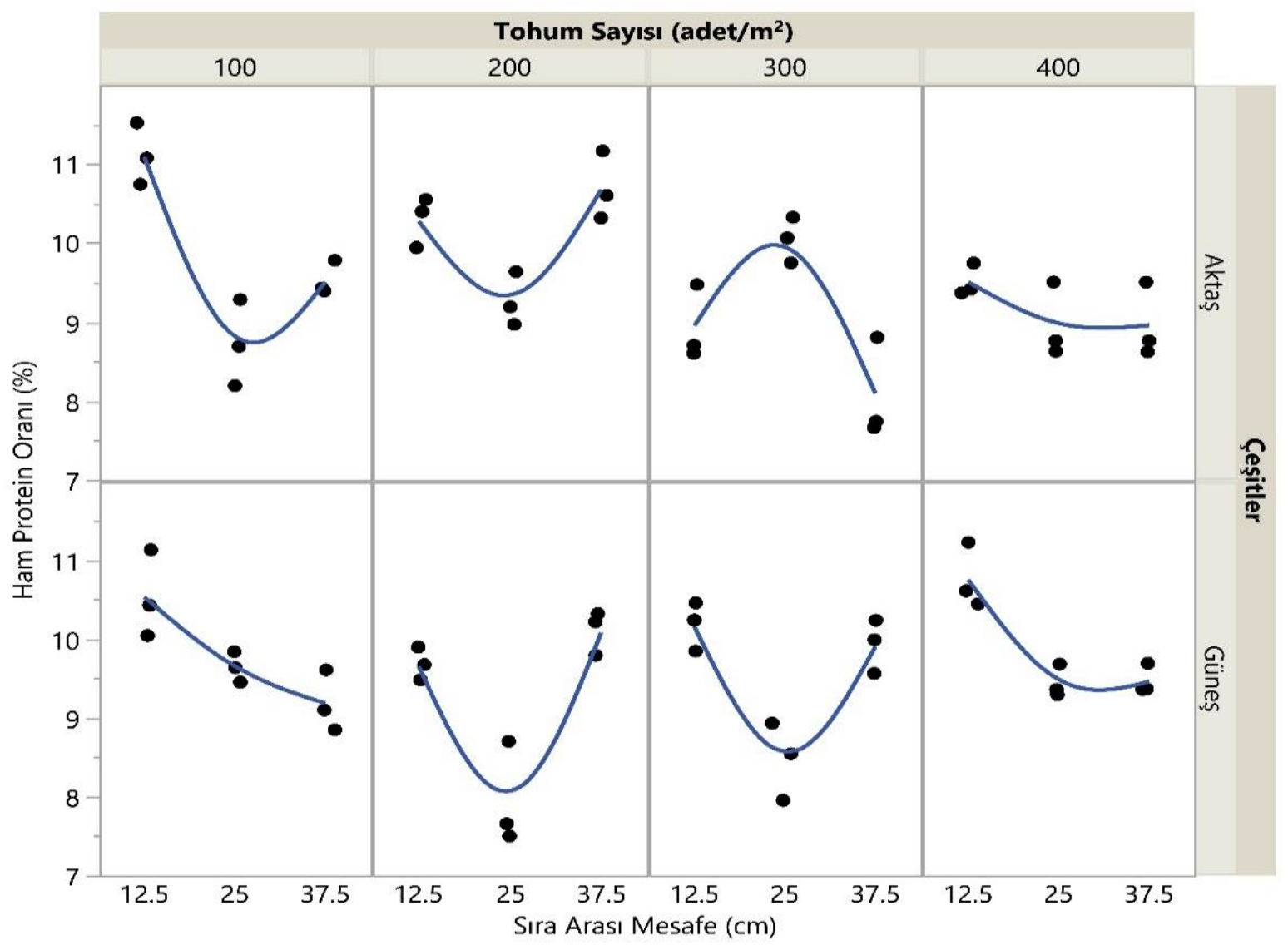

Şekil 4. Bingöl lokasyonunda çeşit, sıra arası mesafe ve tohum sayılarına göre ham protein oranları. 


\section{Sonuç ve Öneriler}

Sonuç olarak, denemelerin yürütüldüğü bölgelerimizde tane amaçlı karabuğday yetiştiriciliğinde $25 \mathrm{~cm}$ sıra arası ve 300 adet $/ \mathrm{m}^{2}$ tohum sayısının kullanılması yüksek tane verimi alınmasını sağlayacaktır. Ekim sıklığı ve tohum sayılarının faktör olarak değerlendirildiği araştırmalarda, varyans analizi yerine regresyon analizinin kullanılması daha yararlı olacaktır.

§: Bu makalenin Çanakkale lokasyonuna ait veriler Sevim AKÇURA'nın yüksek lisans tezinden alınmıştır.

\section{Kaynaklar}

Acar, R. 2009. Karabuğday (Köşeli buğday)'ın Tarımı. Konya Ticaret Borsası Dergisi, 31: 30-37.

Acar, R., Güneş, A., Topal, İ., Gummadov, N. 2011. Farklı bitki sıklıklarının karabuğdayda (Fagopyrum esculentum Moench.) verim ve bazı verim unsurlarına etkisi. Selcuk Journal of Agriculture and Food Sciences, 25(3): 4751.

Bárta, J., Kalinová, J., Moudry, J., Curn, V. 2004. Effects of environmental factors on protein content and composition in buckwheat flour. Cereal Research Communications, 32(4): 541-548.

Brunori, A., Brunori, A., Baviello, G., Marconi, E., Calonna, M., Ricci, M. 2005. The Yield of Five buckwheat (Fagopyrum esculentum Moench) Varieties Grown in Central and Southern Italy. Fagopyrum 22: 98-102.

Campbell, C.G. 1997. Buckwheat (Fagopyrum esculentum Moench.) Promoting the Conservation and Use of Underutilized and Neglected Crops 19. IBPGR.Rome.

Christa, K., Soral-Śmietana, M. 2008. Buckwheat grains and buckwheat products - nutritional and prophylactic value of their components - a review. Czech J. Food Sci., 26: 153-162.

Debnath, N.R., Rasul, M.G., Sarker, M.M.H., Rahman M.H. Paul A.K. 2008. Genetic Divergence in Buckwheat (Fagopyrum esculentum Moench.). Int. J. Sustain Crop Prod., 3(2): 6068.

De Francischi, M.L.P., Salgado, J.M., Leitao, R.F.F. 1994. Chemical, nutritional and technological characteristics of buckwheat and non-prolamine buckwheat flours in comparison of wheat flour. Plant Foods for Human Nutrition, 46(4): 323-329.

Eggum, B.O., Kreft, I., Javornik, B. 1980. Chemical composition and protein quality of buckwheat (Fagopyrum esculentum Moench). Plant Foods for Human Nutrition, 30(3-4): 175-179.
Gubbels, G.H., Campbell, C.G. 1986. Effect of seeding rate on height, yield and quality of large-seeded and semi-dwarf buckwheat genotypes. Canadian Journal of Plant Science, 66(1): 61-66.

Güzelsarı, U., Kan, Y. 2017. Karaman Ekolojik Şartlarında İkinci Ürün Olarak Yetiştirilen Karabuğdayın (Fagopyrum esculentum Moench) Agronomik ve Kalite Özelliklerinin Araştırılması. Selçuk Tarım Bilimleri Dergisi, 3(2): 200-204.

Janos L., Gocs L., 2009. Second Crop buckwheat in Nyırseg regions. Analele Universităţii din Oradea, Fascicula:Protecţia Mediului, 19: 190-195.

JMP. 2016. JMP Users Guide. Version 13.0.0, SAS Institute,Inc., Cary, NC, USA.

Katar, D., Katar, N. 2017. Eskişehir ekolojik koşullarında farklı karabuğday (Fagopyrum esculentum Moench) çeşidinde uygun ekim normunun belirlenmesi. Tarla Bitkileri Merkez Araştırma Enstitüsü Dergisi, 26(1): 31-39.

Myers, R.L., Meinke, L.J. 1994. Buckwheat: A MultiPurpose, Short-Season Alternative (1994). Extension publications (MU).

Park, C.H., Heo, K., Choi, S.Y., Choi, Y.S., Lee, K.C., Kang, Y.K. 2001. Growth analysis of buckwheat influenced by seeding time and planting density. The Journal of The Korean Society of International Agriculture, 11(2): 216-221.

Wijngaard, H., Arendt, E.K. 2006. Buckwheat. Cereal Chemistry, 83(4): 391-401.

Yavuz, H., Yiğit, A., Erekul, O. 2016. Farklı Ekim Sıklıklarının Karabuğdayda (Fagopyrum esculentum Moench.) Verim ve Bazı Tane Kalitesi Özelliklerine Etkisi. Adnan Menderes Üniversitesi Ziraat Fakültesi Dergisi, 13(2): 17-22.

Valenzuela, H., Smith, J. 2002. Buckwheat. Sustainable Agriculture Green Manure Crops. University Of Hawai. Manoba. 